\title{
Comunicação em pauta: jornalismo, cinema, sujeitos e políticas
}

É com satisfação que apresentamos a primeira edição de 2012, dedicada a temas livres. Como editor/a da E-Compós, temos testemunhado a diversidade de assuntos abarcados por nossa área, refletindo um agudo amadurecimento do campo em variadas direções e com incremento constante de qualidade interpretativa. Esse bom nível das submissões tem demandado um esforço substantivo de nossos/as pareceristas, que mantêm a excelência da revista com avaliações precisas e coerentes. A eles/as, nossos sinceros agradecimentos.

A edição de 2012 inaugura uma seção dedicada a artigos gerados a partir de dissertações vencedoras do Prêmio Compós de Dissertações. Em 2011, a dissertação premiada foi de Luiz Marcelo Robalinho Ferraz, defendida pelo Programa de Pós-Graduação da UFPE e sob orientação de Isaltina Gomes. 0 artigo, intitulado Epidemia e memória no discurso jornalístico sobre a dengue, busca identificar o papel da memória discursiva nas notícias sobre a dengue publicadas no Jornal do Commercio de Pernambuco, constatando que 0 noticiário é constituído com base em noções seculares de medo, mal, morte, risco e epidemia.

0 primeiro texto da seção de temas livres é de autoria de Paulo Roberto Gibaldi Vaz, que discute o caráter publicitário 
das reportagens sobre doença mental publicadas em revistas semanais brasileiras nos últimos 15 anos. Com o título Doença mental e consumo nas revistas semanais brasileiras, 0 autor investiga o nexo entre consumo e subjetividade contemporânea pelo estudo das estratégias retóricas que permitem ao indivíduo se conceber como um possível doente e, assim, consumidor de medicamentos. Igualmente resultado de pesquisa sobre publicações semanais, Mayka Castellano discute em seu texto Cultura da autoajuda: o 'surto do aconselhamento'e a bioascese na mídia a tendência observada em alguns veículos de mídia em aconselhar e guiar os/as leitores/as nos mais distintos aspectos de suas vidas. Fechando o pequeno ciclo de debates sobre mídia impressa, 0 texto Entre a realidade jornalística e a realidade social: o jornalismo como forma de acesso ao cotidiano, de Frederico de Mello Brandão Tavares, reflete sobre o impacto do jornalismo na definição cotidiana da realidade social.

Simone Maria Rocha e Letícia Lopes da Silveira discutem a noção de gênero televisivo a partir de perspectivas teóricas de Jesús Martín-Barbero e Jason Mittell no texto intitulado Gênero televisivo como mediação: possibilidades metodológicas para a análise cultural da televisão. Em Desvio de imagens, Anita Leandro analisa, através dos filmes e textos de Guy Debord, a técnica do desvio de imagens já existentes de sua função original para outros contextos, utilizada atualmente por cineastas que trabalham com imagens de arquivo.

0 ensaio de Angela Pintor dos Reis, intitulado Sujeito e discurso da racionalidade técnica na sociedade mediática, discute, a partir da teoria lacaniana e da ideologia de dominação, em que condições a racionalidade técnica constitui um composto com a sociedade mediática para a constituição de um sujeito normalizado. 
0s três últimos textos da edição acionam debates sobre as relações entre mídia e Estado, seja em aspectos conceituais ou através de debates empíricos mais específicos. Mercedes Celina Calzado, em seu texto intitulado Visibilidades da eficácia do Estado, vocabulários penais e gestão política da segurança, discute os procedimentos que 0 Estado argentino tem acionado nos últimos 10 anos para tornar visível a sua ação contra a violência urbana, sobretudo no que concerne às estratégias de controle da visibilidade midiática.

Nem privado nem estatal: a ideia de público como um sistema de comunicação, de Adilson Vaz Cabral Filho, analisa como a noção de complementaridade entre os sistemas privado, público e estatal, prevista na Constituição, se apresenta no caso brasileiro, caracterizado por uma ausência de regulamentação sobre tal sistema. Em O Plano Nacional de Banda Larga brasileiro: um estudo de seus limites e efeitos sócio-políticos, texto que encerra essa edição, Francisco Paulo Jamil Almeida Marques e André Lemos apontam que a atuação do Estado brasileiro ainda não parece ter surtido 0 efeito desejado no que se refere à universalização e ao barateamento na oferta de serviços de telecomunicações.

Mídia impressa, jornalismo, cinema de arquivo, imagens, sujeitos e políticas de comunicação formam o escopo temático dessa edição, apresentando novos enfoques para temáticas consolidadas no campo da Comunicação. Temos certeza de que os textos aqui publicados são representantes da vasta agenda de pesquisa de nossa área, contribuindo com qualidade para a reflexão sobre mídia e sociedade no Brasil.

Esperamos que desfrutem dessa edição. Boa leitura. 